novel and refreshing aspect of the book is the clear feminist spirit captured by the writing styles. Examples include Alice's chapter (chapter 18) that is presented as a conversation between her and her friends, and Middleton and Summers-Bremner's contribution on feminist pedagogy (chapter 10) written as an intergenerational dialogue. In conclusion, I think that this volume should be part of any respectable international collection of feminist work.

\title{
Ann Weatherall
}

doi: $10.1057 /$ palgrave.fr. 9400121

\section{Gendered nations: nationalisms and gender order in the long nineteenth century}

Ida Blom, Karen Hagemann and Catherine Hall, editors; Berg, Oxford, 2000, 347 pp, HbK ISBN 1-85973-2593 £42.00, PbK ISBN 1-859-732-264X£14.99

This edited volume brings together a collection of essays that are a product of the necessary and intense engagement by feminists on the complex connection between the rise of variegated nationalisms and the enmeshing of gender relationships within this. The period is a watershed for the futures that were mapped out for the globe, both in terms of the rise of democratic political movements in Europe, Britain and America (within which women were embedded in a fraught way), relationships between the nations-states of Europe and Britain, and above all for the profound impact it had on colonized peoples all over the world, where imperialism left a lasting legacy. The collection of papers were those that had initially been brought together in a Berlin symposium to evolve an 'international perspective' on 'Nationalisms and Gender Order in the Long Nineteenth Century' (preface, xv).

The book is divided into four distinct parts: Part 1 titled 'Nations, Nationalisms and Gender' contains more conceptual essays by Ida Blom, Geoff Eley, Ruth Roach Pierson and Silke Wenk. While designed to lead overviews of the entire volume, they situate these in methodological debates of our times (Blom has herself contributed to the forging of a women's 'world history' or 'global history' paradigm) and to the critical importance that culture, mythology and the question of representations has acquired in our disciplines (Eley, Roach Pierson and Wenk.) Part 2 is titled 'Nations States, Ethnicity and Gender Order', and contains an analysis by Viktoria Schmidt-Linsenhoff of two paintings by Anne-Loius Girodet (Endymion and Jean Baptiste Belley), which ends with a rather unsatisfactory interlinking with de Sade's defence of 'the discourse of republican sodomy' and the claim that both took 'subversive positions within this discourse' (page 100). 
Catherine Hall's contribution sees the connections between empire, ethnicity (Catholic Emancipation) and 'race' (the slave rebellion in Jamaica 1831) and the 1832 Reform Act in the British Parliament by utilizing Partha Chatterjees's concept of the 'rule of colonial difference' and usefully argues that connections require to be made between gender, class, ethnic, racial hierarchies, which cut across both empire and nation. Both Halls' and Beth Baron's contributions - the latter titled 'The Making of the Egyptian Nation' - are historically nuanced texts, Baron's providing a particularly insightful analysis of the crucial importance of the ending of harem slavery (that had been prevalent within elite Ottoman households) to the emergence and consolidation of an Egyptian national elite by cutting off the trade in female and male slaves, both groups that were traded in to bolster the power of the Ottoman rulers. The question of 'belonging' is then taken up in Lake's contribution on Australian feminists complex relationship to the 'nation' and to the question of aboriginal land rights.

Karen Hagemann and Helen Bradford provide salutary and cogent evidence of women's dedication to war and militarism in certain political conjunctures, Hagemann showing how women were conscripted into a defence of both 'volk' and 'warriors' in Prussia during the wars against Napoleon; Bradford showing the terrifying tenacity of Boer women to the winning of the war against the British in South Africa 1899-1902 (even in the face of hunger and deaths in the concentration camps). The chapter by Margaret Ward reminds us that however hard we try, both the political materiality and the cultural weight of the question of 'community' continues to haunt us in practice, and Ward's call for a 'parity of esteem' as a peace process is instituted in Ireland is one we could usefully heed.

Carroll-Smith Rosenberg has a very interesting analysis of political representation in the American Republic and its political mimesis, both within the heterosexual marital relationship and the circulation of money, the last of which was tantalizingly short. Angelika Shaser writes in this volume on the women's associations in Germany 1894-1914; Jitka Maleckova and Irina Novikova on gender and national identity in Czech National Movement and Latvia respectively, the diverse essays in the volume being held together by a common thread that seeks to unravel the gendered form of nationalisms in the long 19 th century.

All the chapters attempt to detail in different ways the close relationship - indeed the imperative that was present - to rework and transform gender relationships within and between the various nationalist projects. The historical scholarship to date on the construction of a 'feminine domestic' space separates from that of the public (bourgeois) world of male politics inflects and informs all the writings and while I accept that there was a clear need for the (re)domestication of women all over the world in this time, I am by no means convinced that the 'gender order' or 'the modern order of the two sexes' that the chapters constantly reiterate, were self-given during the long 19th century (and that surely is the value of putting this collection together, to show the attempted construction of this). There is an 
assumption in the volume that this did happen, that a clear and separate 'gender order' did take place rather than adopt a more critical and sceptical approach not only to the contested nature of this, but perhaps to its very impossibility in a very real sense (for working women, for harem slaves, for migrant women working on settler plantations) because no 'order' of patriarchy has been able to wield such hegemonic power. This brings me to my second point: the volume is weak both in its lack of close engagement with 'class' and 'empire.' We can only concede that this genteel form of 'gender order' was successfully implemented if we forget the millions of working class, peasant and landless women who formed the majority of womankind. Women in South Asia and Africa continued to do battle with both indigenous and colonial patriarchies well into the middle of the 20 th century, and it is by no means clear that the colonial rule of difference (predicated on the necessity of accumulation on a global scale) could afford to gentrify the vast body of humankind in this world. Contributions that drew upon scholarship on Asia and Africa more fully would have helped raise sharper questions on 'global history' and the workings of gender, nationalism and 'class'.

The strength of 'Gendered Nations' is that it provides useful analyses and overviews of the disenfranchisement of women in Europe and Britain in the heyday of Empire. It is also an engagement with theoretical and methodological questions as to the ways of integrating and carrying out interdisciplinary work that genuinely seeks to link understandings of the worlds of the peoples who were deeply and radically marginalized through the workings of power. I was left with a sense of how much further work is required to evolve frameworks that do justice to this and I look forward to further detailed scholarship that will engage seriously with the call to 'grasp the complexity of the "unequal relations among/between peoples" (p.109), and that will take into account the hierarchies and experiences of women and men across the globe.

doi: 10.1057/palgrave.fr. 9400122

Parita Mukta

\section{Gender, identity and the Irish Press, 1922-1937: embodying the nation}

Louise Ryan; The Edwin Mellen Press, Lewiston, New York, 2002, 320 pp, HbK ISBN 0-7734$7298-3, £ 74.95$

Historians have traditionally used newspapers as one of a number of key sources in providing historical evidence, context and insight into past events and historical debates, thereby allowing them to formulate new arguments and ideas. This fact is as true for the history of women in the Irish Free State throughout the 1920s and 1930 s as it is for any other period in modern history. Moreover, the role and status of women in the Irish Free State has attracted considerable historical attention in 